\title{
IMA Commission on New Minerals, Nomenclature and Classification (CNMNC) - Newsletter 53
}

\author{
Ritsuro Miyawaki ${ }^{1}$, Frédéric Hatert $^{2}$, Marco Pasero ${ }^{3}$, and Stuart J. Mills ${ }^{4}$ \\ ${ }^{1}$ Chairman, CNMNC I Department of Geology, National Museum of Nature and Science, \\ 4-1-1 Amakubo, Tsukuba 305-0005, Japan \\ ${ }^{2}$ Vice-Chairman, CNMNC I Laboratoire de Minéralogie, Université de Liège, Bâtiment B18, \\ Sart Tilman, 4000 Liège, Belgium \\ ${ }^{3}$ Vice-Chairman, CNMNC I Dipartimento di Scienze della Terra, Università di Pisa, \\ Via Santa Maria 53, 56126 Pisa, Italy \\ ${ }^{4}$ Secretary, CNMNC I Geosciences, Museum Victoria, P.O. Box 666, Melbourne, Victoria 3001, Australia \\ Correspondence: Marco Pasero (marco.pasero@unipi.it) \\ Published: 17 February 2020
}

The information given here is provided by the IMA Commission on New Minerals, Nomenclature and Classification for comparative purposes and as a service to mineralogists working on new species.

Each mineral is described in the following format:

- mineral name, if the authors agree on its release prior to the full description appearing in press;

- chemical formula;

- type locality;

- full authorship of proposal;

- e-mail address of corresponding author;

- relationship to other minerals;

- crystal system, space group, structure determined, yes or no;

- unit-cell parameters;

- strongest lines in the X-ray powder diffraction pattern;

- type specimen repository and specimen number;

- citation details for the mineral prior to publication of full description.

Citation details concern the fact that this information will be published in the European Journal of Mineralogy on a routine basis, as well as being added month by month to the Commission's web site.
It is still a requirement for the authors to publish a full description of the new mineral.

No other information will be released by the commission.

\section{New mineral proposals approved in December 2019}

IMA No. 2019-082

Dutrowite

$\mathrm{Na}\left(\mathrm{Fe}_{2.5}^{2+} \mathrm{Ti}_{0.5}\right) \mathrm{Al}_{6}\left(\mathrm{Si}_{6} \mathrm{O}_{18}\right)\left(\mathrm{BO}_{3}\right)_{3}(\mathrm{OH})_{3} \mathrm{O}$

Fornovolasco metarhyolite formation, close to the Boscaccio locality, Fornovolasco, Fabbriche di Vergemoli (LU), Apuan Alps, Tuscany, Italy $\left(44^{\circ} 01^{\prime} 53^{\prime \prime} \mathrm{N}, 10^{\circ} 22^{\prime} 11^{\prime \prime} \mathrm{E}\right)$

Cristian Biagioni*, Ferdinando Bosi, Daniela Mauro, Henrik Skogby, Andrea Dini, and Federica Zaccarini

*E-mail: cristian.biagioni@unipi.it

Tourmaline supergroup

Trigonal: $R 3 m$; structure determined

$a=15.9864(8), c=7.2187(4) \AA$

6.40(42), 4.61(18), 4.24(52), 4.00(60), 2.971(61), 2.585(100), 2.048(41), 1.925(24)

Type material is deposited in the mineralogical collections of the Museo di Storia Naturale, Università di Pisa, Via Roma 79, Calci (PI), Italy, catalogue number 19890

How to cite: Biagioni, C., Bosi, F., Mauro, D., Skogby, H., Dini, A., and Zaccarini, F.: Dutrowite, IMA 2019082, in: CNMNC Newsletter 53, Eur. J. Mineral., 32, https://doi.org/10.5194/ejm-32-209-2020, 2020. 


\section{IMA No. 2019-083}

Fluorapophyllite-( $\left.\mathrm{NH}_{4}\right)$

$\left(\mathrm{NH}_{4}\right) \mathrm{Ca}_{4}\left(\mathrm{Si}_{8} \mathrm{O}_{20}\right) \mathrm{F} \cdot 8 \mathrm{H}_{2} \mathrm{O}$

Vechec andesite quarry, $2.8 \mathrm{~km} \mathrm{SW}$ of the Vechec village, Vranov nad Topl'ou Co., Prešov Region, Slovakia $\left(48^{\circ} 51^{\prime} 09.58^{\prime \prime} \mathrm{N}, 21^{\circ} 36^{\prime} 12.10^{\prime \prime} \mathrm{E}\right)$

Martin Števko*, Jiří Sejkora, Jakub Plášil, Zdeněk Dolníček, and Radek Škoda

*E-mail: msminerals@gmail.com

Apophyllite group

Tetragonal: $P 4 / m n c$; structure determined

$a=8.99336(9), c=15.7910(3) \AA$

7.897(31), 7.812(13), 4.547(14), 3.946(100), 2.985(39), 2.484(11), 2.010(10), 1.579(12)

Type material is deposited in the collections of the Department of Mineralogy and Petrology, National Museum in Prague, Cirkusová 1740, 19300 Prague 9, Czech Republic, catalogue number P1P 44/2019

How to cite: Števko, M., Sejkora, J., Plášil, J., Dolníček, Z., and Škoda, R.: Fluorapophyllite-( $\left.\mathrm{NH}_{4}\right)$, IMA 2019083, in: CNMNC Newsletter 53, Eur. J. Mineral., 32, https://doi.org/10.5194/ejm-32-209-2020, 2020.

\section{IMA No. 2019-085}

Liraite

$\mathrm{NaCa}_{2} \mathrm{Mn}_{2}^{2+}\left[\mathrm{Fe}^{3+} \mathrm{Fe}^{2+}\right] \mathrm{Mn}_{2}^{2+}\left(\mathrm{PO}_{4}\right)_{6}\left(\mathrm{H}_{2} \mathrm{O}\right)_{2}$

Ceferino Namuncurá pegmatite, Pocho Department, Córdoba Province, Argentina ( $31^{\circ} 37^{\prime} 45^{\prime \prime} \mathrm{S}, 65^{\circ} 15^{\prime} 03^{\prime \prime} \mathrm{W}$ )

Marco E. Biglia*, Mark A. Cooper, Edward S. Grew, Jorge A. Sfragulla, María F. Márquez-Zavalía, Alina B. Guereschi, Martin G. Yates, and Miguel A. Galliski

*E-mail: marcobiglia2002@gmail.com

Wicksite group

Orthorhombic: $P c a b$; structure determined

$a=12.608(6), b=12.918(6), c=11.737(4) \AA$

$3.170(22), \quad 2.927(49), \quad 2.856(65), 2.821(25), \quad 2.769(26)$,

2.745(100), 2.706(30), 2.097(29)

Type material is deposited in the collections of the Mineralogy and Geology Museo de Mineralogía y Geología Dr. A. Stelzner, Av. Vélez Sársfield 249, X5000JJC Córdoba, Argentina, catalogue number MS003457

How to cite: Biglia, M. E., Cooper, M. A., Grew, E. S., Sfragulla, J. A., Márquez-Zavalía, M. F., Guereschi, A. B., Yates, M. G., and Galliski, M. A.: Liraite, IMA 2019-085, in: CNMNC Newsletter 53, Eur. J. Mineral., 32, https://doi.org/10.5194/ejm-32-209-2020, 2020.

\section{IMA No. 2019-086}

Arrheniusite-(Ce)

$\mathrm{CaMg}\left[\left(\mathrm{Ce}_{7} \mathrm{Y}_{3}\right) \mathrm{Ca}_{5}\right]\left(\mathrm{SiO}_{4}\right)_{4}\left(\mathrm{Si}_{2} \mathrm{~B}_{3} \mathrm{AsO}_{18}\right)\left(\mathrm{BO}_{3}\right) \mathrm{F}_{11}$
Östanmossa mine, Norberg Municipality, Västmanland County, Sweden $\left(60^{\circ} 05^{\prime} \mathrm{N}, 15^{\circ} 56^{\prime} \mathrm{E}-130 \mathrm{~m}\right.$ a.s.1. $)$

Dan Holtstam*, Luca Bindi, Hans-Jürgen Förster, Paola Bonazzi, and Ulf B. Andersson

*E-mail: dan.holtstam@nrm.se

The Mg-As analogue of hundholmenite-(Y)

Trigonal: $R 3 \mathrm{~m}$; structure determined

$a=10.8082(3), c=27.5196(9) \AA$

$7.739(24), 4.431(43), 3.146(51), 3.010(100), 2.976(70)$, 2.954(32), 2.702(46), 1. 848(24)

Type material is deposited in the mineralogical collections of the Department of Geosciences, Swedish Museum of Natural History, Box 50007, 10405 Stockholm, Sweden, collection number GEO-NRM \#19540155

How to cite: Holtstam, D., Bindi, L., Förster, H.-J., Bonazzi, P., and Andersson, U. B.: Arrheniusite-(Ce), IMA 2019086, in: CNMNC Newsletter 53, Eur. J. Mineral., 32, https://doi.org/10.5194/ejm-32-209-2020, 2020.

\section{IMA No. 2019-087}

Seaborgite

$\mathrm{LiK}_{2} \mathrm{Na}_{6}\left(\mathrm{UO}_{2}\right)\left(\mathrm{SO}_{4}\right)_{5}\left(\mathrm{SO}_{3} \mathrm{OH}\right)\left(\mathrm{H}_{2} \mathrm{O}\right)$

Blue Lizard Mine, Red Canyon, White Canyon District, San Juan Co., Utah, USA $\left(37^{\circ} 33^{\prime} 26^{\prime \prime} \mathrm{N}, 110^{\circ} 17^{\prime} 44^{\prime \prime} \mathrm{W}\right)$

Anthony R. Kampf*, Travis A. Olds, Jakub Plášil, Joe Marty, Samuel N. Perry, Loretta Corcoran, and Peter C. Burns

*E-mail: akampf@nhm.org

New structure type

Triclinic: $P \overline{1}$; structure determined

$a=5.4511(4), \quad b=14.487(1), \quad c=15.873(1) \AA$, $\alpha=76.295(5), \beta=81.439(6), \gamma=85.511(6)^{\circ}$

14.67(97), 5.320(100), 5.093(67), 4.733(75), 3.489(65), 3.331(61), 3.078(61), 2.954(98)

Type material is deposited in the mineralogical collections of the Natural History Museum of Los Angeles County, 900 Exposition Boulevard, Los Angeles, California 90007, USA, catalogue number 74163

How to cite: Kampf, A. R., Olds, T. A., Plášil, J., Marty, J., Perry, S. N., Corcoran, L., and Burns, P. C.: Seaborgite, IMA 2019-087, in: CNMNC Newsletter 53, Eur. J. Mineral., 32, https://doi.org/10.5194/ejm-32-209-2020, 2020.

\section{IMA No. 2019-088}

Adanite

$\mathrm{Pb}_{2}\left(\mathrm{Te}^{4+} \mathrm{O}_{3}\right)\left(\mathrm{SO}_{4}\right)$

North Star Mine, Mammoth, Tintic District, Juab Co., Utah, USA ( $39^{\circ} 55^{\prime} 14^{\prime \prime} \mathrm{N}, 112^{\circ} 06^{\prime} 24^{\prime \prime} \mathrm{W}$ - holotype); Tombstone, Cochise Co., Arizona, USA (cotype)

Anthony R. Kampf*, Robert M. Housley, George R. Rossman, Hexiong Yang, and Robert T. Downs

*E-mail: akampf@nhm.org 
Known synthetic analogue

Monoclinic: $P 22_{1} / n$; structure determined

$a=7.3830(3), \quad b=10.7545(5), \quad c=9.3517(7) \AA$,

$\beta=111.500(8)^{\circ}$

6.744(47), 3.454(80), 3.301(100), 3.114(42), 3.048(73),

2.803(41), 2.745(44), 1.752(45)

Type material is deposited in the mineralogical collections of the Natural History Museum of Los Angeles County, 900 Exposition Boulevard, Los Angeles, California 90007, USA, catalogue number 67505 (holotype), and the RRUFF Project, University of Arizona, USA, deposition number R190033 (cotype)

How to cite: Kampf, A. R., Housley, R. M., Rossman, G. R., Yang, H., and Downs, R. T.: Adanite, IMA 2019088, in: CNMNC Newsletter 53, Eur. J. Mineral., 32, https://doi.org/10.5194/ejm-32-209-2020, 2020.

\section{IMA No. 2019-089}

Celleriite

$\square\left(\mathrm{Mn}_{2}^{2+} \mathrm{Al}\right) \mathrm{Al}_{6}\left(\mathrm{Si}_{6} \mathrm{O}_{18}\right)\left(\mathrm{BO}_{3}\right)_{3}(\mathrm{OH})_{3}(\mathrm{OH})$

Rosina pegmatite, San Piero in Campo, Campo nell'Elba (LI), Elba, Tuscany, Italy

Ferdinando Bosi*, Federico Pezzotta, Alessandra Altieri, Giovanni B. Andreozzi, Paolo Ballirano, and Gioacchino Tempesta

*E-mail: ferdinando.bosi@uniroma1.it

Tourmaline supergroup

Trigonal: $R 3 m$; structure determined

$a=15.9518(4), c=7.1579(2) \AA$

$6.345(45), \quad 4.210(60), \quad 3.983(88), \quad 3.453(55), \quad 2.942(55)$, 2.573(100), 2.036(38), 1.913(26)

Type material is deposited in the mineralogical collections of the Museo Universitario di Scienze della Terra, Sapienza Università di Roma, P.le Aldo Moro, 5, 00185 Rome, Italy, catalogue number 33287/403 (holotype), and the Museo Civico di Storia Naturale, Corso Venezia 55, 20121 Milan, Italy, catalogue number M38847 (cotype)

How to cite: Bosi, F., Pezzotta, F., Altieri, A., Andreozzi, G. B., Ballirano, P., and Tempesta, G.: Celleriite, IMA 2019-089, in: CNMNC Newsletter 53, Eur. J. Mineral., 32, https://doi.org/10.5194/ejm-32-209-2020, 2020.

\section{IMA No. 2019-090}

Grammatikopoulosite

NiVP

Agios Stefanos mine, ca. $10 \mathrm{~km} \mathrm{~S}$ of the Domokos village, Othrys ophiolite, Greece $\left(39^{\circ} 04^{\prime} 59^{\prime \prime} \mathrm{N}, 22^{\circ} 25^{\prime} 59^{\prime \prime} \mathrm{E}\right)$

Luca Bindi*, Federica Zaccarini, Elena Ifandi, Basilios Tsikouras, Chris J. Stanley, Giorgio Garuti, and Daniela Mauro

*E-mail: luca.bindi@unifi.it

Structurally related to florenskyite
Orthorhombic: Pnma; structure determined $a=5.8893(8), b=3.5723(4), c=6.8146(9) \AA$ $2.950(20), 2.785(25), 2.273(60), 2.157(100), 2.118(25)$, 1.915(15), 1.824(15), 1.784(20)

Type material is deposited in the mineralogical collections of the Museo di Storia Naturale, Università di Pisa, Via Roma 79, Calci (PI), Italy, catalogue number 19911

How to cite: Bindi, L., Zaccarini, F., Ifandi, E., Tsikouras, B., Stanley, C. J., Garuti, G., and Mauro, D.: Grammatikopoulosite, IMA 2019-090, in: CNMNC Newsletter 53, Eur. J. Mineral., 32, https://doi.org/10.5194/ejm-32-2092020, 2020.

\section{IMA No. 2019-091}

Ellinaite

$\mathrm{CaCr}_{2} \mathrm{O}_{4}$

In paralavas in the Halamish and Zohar wadi, southern part of the Hatrurim Basin, Israel $\left(31^{\circ} 09^{\prime} 47^{\prime \prime} \mathrm{N}, 35^{\circ} 17^{\prime} 57^{\prime \prime} \mathrm{E}\right.$ - holotype); as mineral phase of an inclusion within diamond, collected from gravel of Sorriso creek, a tributary of Aripuanã River, Mato Grosso, Brazil (11 $20^{\prime} \mathrm{S}, 59^{\circ} 11^{\prime} \mathrm{W}$ - cotype).

Victor V. Sharygin*, Sergey N. Britvin, Felix V. Kaminsky, Richard Wirth, Elena N. Nigmatulina, Grigory A. Yakovlev, Konstantin A. Novoselov, and Mikhail N. Murashko

*E-mail: sharygin@igm.nsc.ru

The $\mathrm{Cr}$ analogue of harmunite

Orthorhombic: Pnma; structure determined

$a=8.868(9), b=2.885(3), c=10.355(11) \AA$

4.434(23), 2.589(54), 2.567(100), 2.424(69), 2.418(62),

2.148(34), 1.767(35), 1.758(22)

Type material is deposited in the collections of the Fersman Mineralogical Museum, Russian Academy of Sciences, Leninskiy Prospekt 18-2, Moscow 119071, Russia, registration number 5439/1 (holotype), the Central Siberian Geological Museum, V.S. Sobolev Institute of Geology and Mineralogy, Siberian Branch of the RAS, prospekt Akademika Koptyuga 3, Novosibirsk 630090, Russia, catalogue number VII102/1 (holotype), and the Vernadsky Institute of Geochemistry and Analytical Chemistry, Kosygin St. 19, Moscow 119334, Russia, F.V. Kaminsky collection, catalogue number 8/108 (cotype)

How to cite: Sharygin, V. V., Britvin, S. N., Kaminsky, F. V., Wirth, R., Nigmatulina, E. N., Yakovlev, G. A., Novoselov, K. A., and Murashko, M. N.: Ellinaite, IMA 2019-091, in: CNMNC Newsletter 53, Eur. J. Mineral., 32, https://doi.org/10.5194/ejm-32-209-2020, 2020.

\section{IMA No. 2019-029a}

Michitoshiite- $(\mathrm{Cu})$

$\mathrm{Rh}\left(\mathrm{Cu}_{1-x} \mathrm{Ge}_{x}\right) \quad 0<x \leq 0.5$

Haraigawa, Misato machi, Kumamoto Prefecture, Kyushu, Japan 
Takahiro Tanaka*, Tadashi Shinmachi, Kota Kataoka, and Daisuke Nishio-Hamane

*E-mail: penta@kuh.biglobe.ne.jp

CsCl-type structure

Cubic: $P m \overline{3} m$

$a=2.977(1) \AA$

2.103(100), 1.717(3), 1.487(15), 1.332(6), 1.216(70)

Type material is deposited in the mineralogical collections of the National Museum of Nature and Science, Tsukuba, Japan, specimen number NSM-46298 (holotype) and NSM16299 (cotype)

How to cite: Tanaka, T., Shinmachi, T., Kataoka, K., and Nishio-Hamane, D.: Michitoshiite-(Cu), IMA 2019029a, in: CNMNC Newsletter 53, Eur. J. Mineral., 32, https://doi.org/10.5194/ejm-32-209-2020, 2020.

\section{New mineral proposals approved in January 2020}

\section{IMA No. 2019-093}

Hagstromite

$\mathrm{Pb}_{8} \mathrm{Cu}^{2+}\left(\mathrm{Te}^{6+} \mathrm{O}_{6}\right)_{2}\left(\mathrm{CO}_{3}\right) \mathrm{Cl}_{4}$

SW cut $\left(35^{\circ} 16^{\prime} 20^{\prime \prime} \mathrm{N}, 116^{\circ} 06^{\prime} 04^{\prime \prime} \mathrm{W}\right.$ - holotype) and Bird Nest drift $\left(35^{\circ} 16^{\prime} 36^{\prime \prime} \mathrm{N}, 116^{\circ} 06^{\prime} 01^{\prime \prime} \mathrm{W}\right.$ - cotype), Otto Mountain, $2.5 \mathrm{~km}$ WNW of Baker, San Bernardino Co., California, USA

Anthony R. Kampf*, Robert M. Housley, Stuart J. Mills, George R. Rossman, and Joe Marty

*E-mail: akampf@nhm.org

New structure type

Orthorhombic: Ibam; structure determined $a=23.688(17), b=9.026(8), c=10.461(8) \AA$

$3.927(80), 3.423(26), 3.286(44), 2.967(100), 2.601(70)$, 2.230(23), 1.964(66), 1.846(19)

Type material is deposited in the mineralogical collections of the Natural History Museum of Los Angeles County, 900 Exposition Boulevard, Los Angeles, California 90007, USA, catalogue numbers 73596 (holotype) and 73597 (cotype)

How to cite: Kampf, A. R., Housley, R. M., Mills, S. J., Rossman, G. R., and Marty, J.: Hagstromite, IMA 2019093, in: CNMNC Newsletter 53, Eur. J. Mineral., 32, https://doi.org/10.5194/ejm-32-209-2020, 2020.

\section{IMA No. 2019-095}

\section{Waipouaite}

\section{$\mathrm{Ca}_{3} \mathrm{~V}_{5}^{4+} \mathrm{O}_{9}\left[\mathrm{Si}_{2} \mathrm{O}_{5}(\mathrm{OH})_{2}\right]\left[\mathrm{Si}_{3} \mathrm{O}_{7}(\mathrm{OH})_{2}\right] \cdot 11 \mathrm{H}_{2} \mathrm{O}$}

Aranga Quarry, Aranga, Kaipara District, Northland Region, New Zealand $\left(35^{\circ} 44^{\prime} 06^{\prime \prime} \mathrm{S}, 173^{\circ} 34^{\prime} 47^{\prime \prime} \mathrm{E}\right)$

Peter Elliott* and Anthony R. Kampf

*E-mail: peter.elliott@adelaide.edu.au

New structure type
Monoclinic: $P 2{ }_{1} / c$; structure determined

$a=12.843(3), \quad b=23.589(5), \quad c=11.560(2) \AA$,

$\beta=115.54(3)^{\circ}$

11.78(100), 9.54(16), 7.85(19), 6.29(32), 5.92(31), 5.22(21), $3.140(18), 2.850(17)$

Type material is deposited in the mineralogical collections of the South Australian Museum, North Terrace, Adelaide, South Australia 5000, Australia, registration number G34802 How to cite: Elliott, P. and Kampf, A. R.: Waipouaite, IMA 2019-095, in: CNMNC Newsletter 53, Eur. J. Mineral., 32, https://doi.org/10.5194/ejm-32-209-2020, 2020.

\section{IMA No. 2019-096}

Eliopoulosite

$\mathrm{V}_{7} \mathrm{~S}_{8}$

Agios Stefanos mine, ca. $10 \mathrm{~km} \mathrm{~S}$ of the Domokos village, Othrys ophiolite, Greece $\left(39^{\circ} 04^{\prime} 59^{\prime \prime} \mathrm{N}, 22^{\circ} 25^{\prime} 59^{\prime \prime} \mathrm{E}\right)$

Luca Bindi*, Federica Zaccarini, Paola Bonazzi, Tassos Grammatikopoulos, Basilios Tsikouras, Chris J. Stanley, and Giorgio Garuti

*E-mail: luca.bindi@unifi.it

Known synthetic analogue

Trigonal: $P 3_{2} 21$; structure determined

$a=6.689(3), c=17.403(6) \AA$

2.896(29), 2.591(45), 2.049(100), 1.672(40), 1.608(10), 1.296(20), 1.096(15), 1.024(12)

Type material is deposited in the mineralogical collections of the Museo di Storia Naturale, Università di Pisa, Via Roma 79, Calci (PI), Italy, catalogue number 19911

How to cite: Bindi, L., Zaccarini, F., Bonazzi, P., Grammatikopoulos, T., Tsikouras, B., Stanley, C. J., and Garuti, G.: Eliopoulosite, IMA 2019-096, in: CNMNC Newsletter 53, Eur. J. Mineral., 32, https://doi.org/10.5194/ejm-32-2092020, 2020.

\section{IMA No. 2019-097}

Kesebolite-(Ce)

$\mathrm{CeCa}_{2} \mathrm{Mn}\left(\mathrm{AsO}_{4}\right)\left(\mathrm{SiO}_{3}\right)_{3}$

Kesebol Mn-(Fe-Cu) deposit, Åmål Municipality, Västra Götaland, Sweden ( $58^{\circ} 59^{\prime} 04^{\prime \prime} \mathrm{N}, 12^{\circ} 31^{\prime} 47^{\prime \prime} \mathrm{E}-130 \mathrm{~m}$ a.s.l.)

Dan Holtstam*, Luca Bindi, Andreas Karlsson, Jörgen Langhof, Thomas Zack, Paola Bonazzi, and Anders Persson *E-mail: dan.holtstam@nrm.se

New structure type

Monoclinic: $P 21 / c$; structure determined

$a=6.7382(3), \quad b=13.0368(6), \quad c=12.0958(6) \AA, \quad \beta=$ $98.578(2)^{\circ}$

6.50(22), 5.96(54), 5.70(42), $3.228(58), \quad 3.138(84)$, 3.114(100), 2.924(84), 2.908(63)

Type material is deposited in the mineralogical collections of the Department of Geosciences, Swedish Museum of Natural 
History, Box 50007, 10405 Stockholm, Sweden, collection number GEO-NRM \#20100343

How to cite: Holtstam, D., Bindi, L., Karlsson, A., Langhof, J., Zack, T., Bonazzi, P., and Persson, A.: Kesebolite-(Ce), IMA 2019-097, in: CNMNC Newsletter 53, Eur. J. Mineral., 32, https://doi.org/10.5194/ejm-32-209-2020, 2020.

IMA No. 2019-099

Ramosite

$\mathrm{Pb}_{25.7} \mathrm{Sn}_{8.3} \mathrm{Mn}_{3.4} \mathrm{Sb}_{6.4} \mathrm{~S}_{56.2}$

Uchucchacua polymetallic deposit, Oyón District, Catajambo, Lima department, Peru $\left(10^{\circ} 37^{\prime} 23^{\prime \prime} \mathrm{S}, 76^{\circ} 41^{\prime} 17^{\prime \prime} \mathrm{W}\right)$

Frank N. Keutsch*, Shao-Liang Zheng, Dan Topa, and Chris Stanley

*E-mail: keutsch@seas.harvard.edu

The Mn analogue of franckeite

Monoclinic: $C 2 / m$ (Q-slab), $P 2{ }_{1}$ (H-slab)

$a=5.82, b=5.92, c=17.65 \AA, \beta=99.1^{\circ}$ (Q-slab)

$a=6.23, b=3.69, c=17.59 \AA, \beta=93.3^{\circ}$ (H-slab)

$3.48-3.59(58), \quad 3.23-3.32(13), \quad 3.13-3.20(4), \quad 2.86-$ $3.09(100), \quad 2.54-2.59(7), \quad 2.36-2.42(14), \quad 2.18-2.25(73)$, $1.96-2.07(43)$

Type material is deposited in the mineralogical collections of the Naturhistorisches Museum Wien, Burgring 7, 1010 Vienna, Austria, catalogue number O1798, and the Mineralogical \& Geological Museum, Harvard University, Cambridge, Massachusetts 02138, USA, specimen numbers 2019.18.1 and 2019.18.2

How to cite: Keutsch, F. N., Zheng, S.-L., Topa, D., and Stanley, C.: Ramosite, IMA 2019-099, in: CNMNC Newsletter 53, Eur. J. Mineral., 32, https://doi.org/10.5194/ejm-32-2092020, 2020.

\section{Nomenclature/classification proposals approved in December 2019}

\section{IMA 19-G: discreditation of ferrotellurite}

Proposal 19-G is accepted, and the ill-defined mineral ferrotellurite is discredited. Indeed, this species has been shown to be equivalent to keystoneite, $\mathrm{Mg}_{0.5} \mathrm{NiFe}^{3+}\left(\mathrm{Te}^{4+} \mathrm{O}_{3}\right)_{3} \cdot 4.5 \mathrm{H}_{2} \mathrm{O}$.

\section{IMA 19-H: discreditation of heliophyllite}

Proposal $19-\mathrm{H}$ is accepted, and heliophyllite is discredited. This species is identical to ecdemite, $\mathrm{Pb}_{6} \mathrm{As}_{2} \mathrm{O}_{7} \mathrm{Cl}_{4}$.

\section{Revised chemical formula}

A paper on the mineral ilmajokite has been recently published (IUCrJ, 7, 2020; 121-128) in which the ideal chemical formula of the mineral is given as $\mathrm{Na}_{11} \mathrm{KBaCe}_{2} \mathrm{Ti}_{12} \mathrm{Si}_{37.5} \mathrm{O}_{94}(\mathrm{OH})_{31} \cdot 29 \mathrm{H}_{2} \mathrm{O}$. With respect to the previously accepted formula, there is a new chemical element $(\mathrm{K})$; moreover $\mathrm{Ba}$ and $\mathrm{Ce}$, which were previously put together with $\mathrm{Na}$ as subordinate cations, acquire now the status of species-forming constituents, as the structural study clearly indicates that they are partitioned at specific crystallographic sites. These data were examined carefully by the CNMNC officers and were considered reliable. Accordingly it was agreed to modify the formula of the mineral in the official IMA List of Minerals. Moreover, the occurrence of a REE as a species-forming element implies the renaming of ilmajokite to ilmajokite-(Ce). 